Organic $\mathrm{C}$ and $\mathrm{N}$ stabilization in a forest soil: evidence from sequential density fractionation

P. Sollins, C. Swanston, M. Kleber, T. Filley, M. Kramer, S. Crow, B. Caldwell, K. Lajtha, R. Bowden

July 22, 2005

Soil Biology and Biochemistry 
This document was prepared as an account of work sponsored by an agency of the United States Government. Neither the United States Government nor the University of California nor any of their employees, makes any warranty, express or implied, or assumes any legal liability or responsibility for the accuracy, completeness, or usefulness of any information, apparatus, product, or process disclosed, or represents that its use would not infringe privately owned rights. Reference herein to any specific commercial product, process, or service by trade name, trademark, manufacturer, or otherwise, does not necessarily constitute or imply its endorsement, recommendation, or favoring by the United States Government or the University of California. The views and opinions of authors expressed herein do not necessarily state or reflect those of the United States Government or the University of California, and shall not be used for advertising or product endorsement purposes. 


\title{
Organic $\mathbf{C}$ and $\mathbf{N}$ stabilization in a forest soil: evidence from sequential density fractionation
}

\author{
Phillip Sollins ${ }^{\mathrm{a}, *}$, Christopher Swanston ${ }^{\mathrm{b}}$, Markus Kleber ${ }^{\mathrm{c}}$, Timothy Filley ${ }^{\mathrm{d}}$, Marc Kramer ${ }^{\mathrm{e}}$, \\ Susan Crow ${ }^{a}$, Bruce A. Caldwell ${ }^{a}$, Kate Lajtha ${ }^{a}$, and Richard Bowden ${ }^{f}$ \\ ${ }^{a}$ Oregon State University, Corvallis, OR 97331, USA \\ ${ }^{b}$ Lawrence Livermore National Laboratory, Livermore, CA 94550,USA \\ ${ }^{c}$ Lawrence Berkeley National Laboratory, Berkeley, CA 94720, USA \\ ${ }^{\mathrm{d}}$ Purdue University, West Lafayette, IN 47907, USA \\ ${ }^{\mathrm{E}}$ University California Santa Cruz, Santa Cruz, CA 95064, USA \\ ${ }^{\mathrm{f}}$ Allegheny College, Meadville, PA, 16335, USA
}

\begin{abstract}
In mineral soil, organic matter (OM) accumulates mainly on and around surfaces of silt- and clay-size particles. When fractionated according to particle density, $\mathrm{C}$ and $\mathrm{N}$ concentration (per $\mathrm{g}$ fraction) and $\mathrm{C} / \mathrm{N}$ of these soil organo-mineral particles decrease with increasing particle density across soils of widely divergent texture, mineralogy, location, and management. The variation in particle density is explained potentially by two factors: 1) a decrease in the mass ratio of organic to mineral phase of these particles, and 2) variations in density of the mineral phase. The first explanation implies that the thickness of the organic accumulations decreases with increasing particle density. The decrease in $\mathrm{C} / \mathrm{N}$ can be explained at least partially by especially stable sorption of cationic peptidic compounds (amine, amide, and pyrrole) directly to mineral surfaces, a phenomenon well documented both empirically and theoretically. These peptidic compounds, along with ligand-exchanged carboxylic compounds, could then form a stable inner organic layer onto which less polar organics could sorb more readily than onto the highly charged mineral surfaces (“onion" layering model).
\end{abstract}

To explore mechanisms underlying this trend in $\mathrm{C}$ concentration and $\mathrm{C} / \mathrm{N}$ with particle density, we sequentially density fractionated an Oregon andic soil at 1.65, 1.85, 2.00, 2.28, and $2.55 \mathrm{~g}$ $\mathrm{cm}^{-3}$ and analyzed the six fractions for measures of organic matter and mineral phase properties.

All measures of OM composition showed either: (1) a monotonic change with density, or (2) a monotonic change across the lightest fractions, then little change over the heaviest fractions. Total C, N, and lignin phenol concentration all decreased monotonically with increasing density, and ${ }^{14} \mathrm{C}$ mean residence time (MRT) increased with particle density from ca. $150 \mathrm{y}$ to $>980 \mathrm{y}$ in the four organo-mineral fractions. In contrast, $\mathrm{C} / \mathrm{N},{ }^{13} \mathrm{C}$ and ${ }^{15} \mathrm{~N}$ concentration all showed the second pattern. All these data are consistent with a general pattern of an increase in extent of microbial processing with increasing organo-mineral particle density, and also with an "onion" layering model. 
X-ray diffraction before and after separation of magnetic materials showed that the sequential density fractionation isolated pools of differing mineralogy, with layer-silicate clays dominating in two of the intermediate fractions and primary minerals in the heaviest two fractions. There was no indication that these differences in mineralogy controlled the differences in density of the organo-mineral particles in this soil. Thus, our data are consistent with the hypothesis that variation in particle density reflects variation in thickness of the organic accumulations and with an "onion" layering model for organic matter accumulation on mineral surfaces. However, the mineralogy differences among fractions made it difficult to test either the layer-thickness or "onion" layering models with this soil. Although sequential density fractionation isolated pools of distinct mineralogy and organic-matter composition, more work will be needed to understand mechanisms relating the two factors.

Keywords: soil organic matter, particle density, ${ }^{13} \mathrm{C},{ }^{15} \mathrm{~N},{ }^{14} \mathrm{C}$, MRT, lignin, hydroxyfatty acids, cutin, suberin, X-ray diffraction, glycoprotein, amino sugar, protein, amino acid, smectite, magnetite, acid/aldehyde ratio, carbon, nitrogen, sulfur, soil C stabilization.

\section{Introduction}

Understanding controls on soil organic matter (SOM) storage is critical to quantifying changing rates of $\mathrm{C}$ cycling and storage in response to global climate change. Additionally, SOM plays critical roles in governing agricultural and forest soil dynamics and ecosystem productivity. Soil organic matter $(\mathrm{OM})$ dynamics are complex, requiring understanding of biological and chemical interactions between organic compounds and mineral soil constituents. In mineral soil, OM accumulates mainly on and around surfaces of silt- and clay-size particles. When fractionated according to density, $\mathrm{C}$ and $\mathrm{N}$ concentration (per $\mathrm{g}$ fraction) and $\mathrm{C} / \mathrm{N}$ of these soil organomineral particles decrease with increasing particle density across soils of widely divergent texture, mineralogy, location, and management (Fig. 1). Portions of this trend in $\mathrm{C} / \mathrm{N}$ are easily understood. The lightest fractions $\left(<1.6-1.8 \mathrm{~g} \mathrm{~cm}^{-3}\right)$ have high $\mathrm{C} / \mathrm{N}$ due simply to the high content of plant-derived polysaccharides, lignin, cutin, suberin, and charcoal. The continued decrease in C/N above densities $>2.0 \mathrm{~g} \mathrm{~cm}^{-3}$ was commented on by Oades (1989) but remains unexplained.

To understand this trend in $\mathrm{C} / \mathrm{N}$, it is helpful to replot the data underlying Fig. 1 to show particle density as a function of $\mathrm{C}$ content (Fig. 2). The strong inverse relation suggests that much of the variation in density of the soil particles is due to differences in C concentration. Alternatively, some could also be due to variation in density of the mineral or organic phases. The first explanation, however, implies that the thickness of the organic accumulations decreases with increasing particle density. Thus it may be reasonable to recast the trend in $\mathrm{C} / \mathrm{N}$ with density as reflecting a decrease in $\mathrm{C} / \mathrm{N}$ with decreasing thickness of the organic layer accumulated on mineral surfaces. Layering, perhaps, is not the most the best term to describe this phenomenon, as there is ample evidence that the organic matter is distributed discontinuously over the mineral surfaces at scales $<<1 \mu \mathrm{m}$ (Mayer, 1999; Kaiser and Guggenberger, 2003; Zimmerman et al., 2004). However, scanning electron microscopy at scales $>1 \mu \mathrm{m}$ shows very few clean mineral surfaces in the A horizons of most mineral soils (e.g., Spycher et al., 1986), thus we use "layer" here for convenience. 
A low $\mathrm{C} / \mathrm{N}$ in thin organic layers on mineral surfaces can be explained at least partially by especially stable sorption of cationic nitrogenous compounds (glycoproteins, amino sugars, and proteins) directly to mineral surfaces, a phenomenon well documented both empirically and theoretically. Much soil organic N occurs as peptidic compounds (amide, amine, and pyrrole N; Schulten and Schnitzer, 1998, Knicker, 2000; Knicker et al.. 2000; DiCosty et al., 2003; Martens and Loeffelmann, 2003; Schmidt-Rohr et al., 2004). A significant portion may occur as heterocyclic N (Mertz et al. 2005; Smernik and Baldcok, 2005), which can be biotic (e.g., nucleic acids), combustion products associated with charcoal, or fossil organics inherited from sedimentary rock particles. The amount of heterocyclic $\mathrm{N}$ in soils in still unclear, however.

There is considerable evidence that peptidic compounds bind especially stably to mineral surfaces (Theng, 1979, Chevallier et al., 2003; Wershaw, 2004). Strong sorption of defined protein on clean clays is well documented, although values vary over nearly five orders of magnitude, related apparently to the nature of the sorbate, sorbent, and experimental conditions (Theng, 1979, Burchill et al., 1981; Wang and Lee, 1993; De Cristoforo and Violante, 2001; Ding and Henrichs, 2002). The highest levels reported for clean clays (e.g., Burchill et al., 1981, p. 269; DeCristoforo and Violante, 2001) and buried ceramics (Craig and Collins, 2002) approach $1 \mathrm{~g}$ protein/g clay, implying a soil C concentration greater than that allowed in Soil Taxonomy for a mineral soil horizon (Soil Survey Staff, 1999). In addition, considerable empirical data for marine sediments and riverine particles show strong and stable binding of amino acids to clay minerals (Hedges and Hare, 1987; Wang and Lee, 1993; Mayer et al., 1995; Arnarson and Keil, 2001; Aufdenkampe et al., 2001). These peptidic compounds could then form a stable inner organic layer onto which less polar organics could sorb more readily than onto the highly charged mineral surfaces, as well as a reactive chemical template for further coupling and cross-linking of organic compounds. We refer to this idea as an "onion" layering model, evidence for which has been obtained by Murphy et al. (1990) who showed that sorption of acidic organics on clean clays greatly increased subsequent sorption of hydrophobic compounds.

Here we explore changes in SOM and the validity of our onion-layering model through a range of densities in an andic forest soil from the Oregon Cascade range. We isolated physical soil fractions using sequential density fractionation (SDF), then analyzed each fraction for measures of both organic matter composition (total $\mathrm{C}$ and $\mathrm{N} ;{ }^{14} \mathrm{C}$; stable $\mathrm{C}$ and $\mathrm{N}$ isotopes; lignin phenol content and oxidation state; hydroxyl fatty acids as a measure of cutin and suberin) and mineralogy (X-ray diffraction and $\mathrm{NaF}$ reaction).

\section{Methods}

\subsection{Site and soil description}

Soil was collected adjacent to the Detritus Input and Removal Treatments (DIRT) study plot \#18 (Lajtha et al. in press) at the Andrews Experimental Forest in western Oregon. The soil, an Andic Dystrudept (J. Dixon and J. Noller, Oregon State University, pers. communic.), is

46 developed in an alluvial/colluvial fan that now forms a gently sloping surface about $20 \mathrm{~m}$ above 
Lookout Creek. Rocks upslope (the presumed source of the deposit) are mainly ash-flow tuffs, both welded and non-welded (Swanson and James 1975), andesitic/basaltic in chemistry. The site is well west (upwind) of the active Cascade volcanoes, thus ash fall has not been a significant factor. The climate is Mediterranean with warm, dry summers and cool, wet winters. Mean annual temperature at the nearby headquarters site averaged $8.8^{\circ} \mathrm{C}$ and annual precipitation was $2200 \mathrm{~mm}$ during 1974-2003 (Sulzman et al., 2005).

The forest overstory is mixed old-growth Douglas-fir (Pseudotsuga menziesii), western hemlock (Tsuga heterophylla) and western redcedar (Thuja plicata). The Douglas-fir originated in a stand-replacement fire ca. 1500 . The overstory is relatively sparse $\left(25\right.$ dominants ha $\left.{ }^{-1}\right)$, permitting good growth of understory species including western hemlock, Pacific yew (Taxus brevifolia), vine maple (Acer circinatum), Pacific dogwood (Cornus nuttallii), huckleberry (Vaccinium spp.), and sword fern (Polystichum munitum). Mosses are abundant in some areas but not where we sampled.

\subsection{Sample collection and handling}

For sequential density fractionation, a single large A-horizon sample was collected (July 2004) just outside the SW corner of DIRT plot 18 (Lajtha et al., in press) in an area that had not been disturbed during plot installation. The $\mathrm{O}$ horizon (including all recognizable coarse wood fragments) and the upper $2 \mathrm{~cm}$ of mineral horizon soil were discarded to decrease the amount of organic debris in the sample. Soil was returned immediately to the laboratory, sieved by pushing the soil through a 2 -mm screen, mixed thoroughly, and stored in a cooler $\left(2^{\circ} \mathrm{C}\right)$ for several days until fractionation. This large sample was then subsampled for laboratory analyses. Given the sample size $(n=1)$, any variability reported thus represents effects of subsampling and lab procedures, not spatial variability at the site.

\subsection{Sequential density fractionation (SDF)}

Density fractionation involved centrifugation of soil suspended in sodium polytungstate (SPT), aspiration of the floating material and supernatant, and vacuum filtration (Strickland et al., 1992; Swanston et al., 2005). First, three 15-g samples were set aside to determine moisture content (26\%). Then, eight subsamples ( $30 \mathrm{~g}$ fresh weight) were placed in 225 -ml polycarbonate centrifuge tubes with conical bottoms and 5-cm diameter mouths. Such tubes allow excellent physical separation of sediment and floating material, while their transparency facilitates aspiration of the supernatant without disturbing the sediment. Four-place tube racks and vacuum manifolds greatly sped operations. Samples were shaken $2-3 \mathrm{hr}$ on a shaker table. The intent was to disperse only the weakly bound aggregates. The soil suspensions were then centrifuged at $2400 \mathrm{rpm}(970 \mathrm{~g})$ in a swinging-bucket rotor for 20-30 min, after which floating material was aspirated and rinsed with deionized $\mathrm{H}_{2} \mathrm{O}$ on a glass fiber filter (Whatman GF/F, $0.7 \mu \mathrm{m}$ particle retention). This procedure was done twice at each density, and the aspirated materials from both cycles for a given density were combined. The density of the remaining SPT solution was then increased by adding the next density SPT solution to the centrifuge tubes. Density was assumed to be somewhat light for cycle 1, because of dilution by residual lighter medium. We initially selected target densities of $1.65,1.85,2.00,2.25$, and $2.50 \mathrm{~g} \mathrm{~cm}^{-3}$ based on previous studies and 
known densities of typical soil primary and secondary minerals (see below). The densities actually reported $\left(1.65,1.85,2.00,2.28\right.$, and $\left.2.55 \mathrm{~g} \mathrm{~cm}^{-3}\right)$ were those measured at the end of cycle 2 by pipetting and weighing $1 \mathrm{~mL}$ of supernatant remaining above the sediment after aspiration. Densities for a given fraction were usually within $0.03 \mathrm{~g} \mathrm{~cm}^{-3}$ of the target value (never more than $0.05 \mathrm{~g} \mathrm{~cm}^{-3}$ different). Fractions from the 8 subsamples were composited randomly (same choice of subsamples for all density fractions) into two samples for subsequent laboratory analysis. All laboratory replicates agreed closely; only the means are reported here. To provide more material, a second density fractionation was done in January 2005 after the composite soil sample had been stored field moist at $2^{\circ} \mathrm{C}$ for about 6 months.

\subsection{Organic matter analyses}

Organic C and N concentrations were determined in triplicate on a Leco CNS-2000 elemental analyzer. Sample size was $0.1-0.2 \mathrm{~g}$ for the three lightest fractions, and $0.4-0.5 \mathrm{~g}$ for the three heaviest fractions. Samples were also analyzed for $\delta^{13} \mathrm{C}$ and $\delta^{15} \mathrm{~N}$ with a 20/20 ANCA GSL continuous-flow isotope-ratio mass spectrometer (PDZ Europa, Cheshire, UK) at the Rosenstiel School of Marine Science, University of Miami.

Density fractions were analyzed for lignin (Hedges and Mann, 1979) and cutin and suberin acids (hydroxyl and fatty acids and diacids: Goñi and Hedges, 1990; Rumpel et al., 2004) via cupricoxide (CuO) oxidation. Briefly, small amounts of sample (enough to yield approximately 1-3 $\mathrm{mg} \mathrm{C}$ ) were weighed into Monel reaction vessels (Prime Focus) with $\mathrm{CuO}$ powder and ferrous ammonium sulfate, and purged under Ar gas for at least 4 hours. The vessels were then filled with $2 \mathrm{M} \mathrm{NaOH}$, placed in a rotating carousel, heated to $150^{\circ} \mathrm{C}\left(4.2^{\circ} \mathrm{C} \mathrm{min}{ }^{-1}\right)$ and held for 150 minutes (total time: 3 hours). After heating, the samples were opened and ethyl vanillin and DL12 hydroxystearic acid were added as internal recovery standards (IRS). The high molecularweight, acid-insoluble organics were then precipitated by acidification, and soluble ligninderived phenols and functionalized fatty acids were extracted into diethyl ether, blown to dryness, re-diluted in $100 \mu \mathrm{L}$ pyridine, and stored at $-20^{\circ} \mathrm{C}$ until further processing.

Lignin phenols were quantified by analysis of the trimethylsilane (TMS) derivatives of eight lignin phenol monomers (vanillin, acetovanillone, syringealdehyde, vanillic acid, acetosyringone, syringic acid, $p$-hydroxycinnamic acid, and ferulic acid) using a 5 point calibration curve for each of the target compounds relative to the IRS ethyl vanillin. The trimethylsilane (TMS) derivatives of nine hydroxy fatty acids and fatty di-acids were analyzed based upon target and proxy standards relative to the IRS of DL-12, hydroxystearic acid in a five-point calibration curve using extracted ion profiles. Total cutin and suberin acids are defined here as the sum of 16-hydroxyhexadecanoic acid, hexadecanoic diacid, 18hydroxyoctadec-9enoic acid, and semiquantitation of 9,16\&10,16 dihydroxyhexadecanoic acid, 9-octadecene1,18dioic acid, 7\&8 hydroxyhexadecane dioic, 9,10,18 trihydroxyoctadec12enoic, and 9,10,18-trihydroxyoctanoic acid. A Shimadzu QP5050A quadrupole mass spectrometer interfaced to a GC17a gas chromatograph was used to identify and quantify selected mass fragments of the IRS and target compounds. Successful TMS derivatization of samples and GC/MS instrument performance was verified with a methyl 3,4-dimethoxybenzoate recovery standard, which was added prior to derivatization of all samples and blanks. 
The lignin analyses provide information on the oxidation state of the lignin compounds and the nature of the plant inputs to the soil. For example, information about the oxidation state of lignin can be inferred from the relative abundance of vanillic acid to vanillin $(\mathrm{Ac} / \mathrm{Al})_{\mathrm{v}}$ and syringic acid to syringealdehyde, as microbial degradation of lignin increases the ratio of carboxylic acids to aldehydes (Hedges et al., 1988; Filley et al., 2000). Additionally, the nature of plant inputs to the soil can be inferred by comparing the yield of syringyl or cinnamyl compounds normalized to yield of vanillyl compounds (S/V and C/V, respectively) (Hedges and Mann 1979).

Radiocarbon was measured on the Van de Graaff FN accelerator mass spectrometer (AMS) at the Center for Accelerator Mass Spectrometry at Lawrence Livermore National Laboratory, CA. Samples were prepared for AMS analysis by combustion to $\mathrm{CO}_{2}$ in the presence of $\mathrm{CuO}$ and subsequent reduction of the $\mathrm{CO}_{2}$ onto iron powder in the presence of $\mathrm{H}_{2}$ (Vogel et al., 1987). Radiocarbon data are expressed according to Stuiver and Polach (1977) as $\Delta^{14} \mathrm{C}$, the deviation in parts per thousand from the absolute international standard activity $\left({ }^{14} \mathrm{C}:{ }^{12} \mathrm{C}\right.$ ratio of oxalic acid corrected for decay since 1950). The $\Delta^{14} \mathrm{C}$ values were adjusted for mass-dependent fractionation based on measured $\delta^{13} \mathrm{C}$ values for each fraction (Table 1). Mean residence times of density fractions were calculated with a time-dependent steady-state model (Trumbore, 1993; Trumbore et al., 1995, Gaudinski et al., 2000, Torn et al., 2002). The two fundamental assumptions of the model are: 1) inputs equal losses for each pool through time, though $\Delta^{14} \mathrm{C}$ varies; and 2) the $\Delta^{14} \mathrm{C}$ of inputs to all pools is equal to that of the atmosphere in the previous year. Thus, the model does not account for multi-year lags before input or transfer between pools, so resulting MRTs should be considered maximum values. Yearly atmospheric values $\left(\Delta{ }^{14} \mathrm{C}\right)$ used in the model were based on three chronologies, beginning in calendar year 1511 (Stuiver et al., 1998; Hua and Barbetti, 2004; Levin and Kromer, 2004).

\subsection{Mineralogical analyses}

$\mathrm{NaF}$ reaction $\mathrm{pH}$ was measured 2 minutes after adding $1.0 \mathrm{M} \mathrm{NaF}$ to 0.3 to $0.6 \mathrm{~g}$ of fraction (depending on amounts available) to yield a 1:50 soil:solution ratio. Qualitative identification of soil mineralogy in bulk soil and density fractions was based on X-ray diffraction. Samples were hand-ground with a mortar and pestle to a mean particle size $<200 \mu \mathrm{m}$, then back-loaded into a 2.5-cm diameter circular-cavity holder and run on a PANanalytical X'Pert Pro instrument using Co-K $\alpha$ radiation at $40 \mathrm{kV}$ and $40 \mathrm{~mA}$. Diffraction patterns were recorded by step scanning from $3-100^{\circ} 2 \theta$, with the sample spinning at 2 revolutions per second. Phase identification and peak area determinations were done using the X'pert High Score plus software.

\section{Results}

\subsection{Physical appearance, dry weight, and $C$ and $N$}

Fractions are referred to hereafter as F1 through F6 as indicated in Table 1. Light microscopy (Fig. 3) showed that fibrous material and charcoal decreased in abundance steadily with increasing density and were nearly absent from fractions F3-F6. Sand- and coarse silt-size mineral fragments were largely restricted to F5 and F6.

44 
Concentrations of $\mathrm{C}$ and $\mathrm{N}$ decreased with increasing particle density from $\mathrm{F} 1$ to $\mathrm{F} 6$ (Table 1). Dry weight, as percent of total soil material, peaked strongly in F4 (Fig. 4). Although F1 comprised only a small portion of the total soil weight, it accounted for more of the total soil C than any other fraction (Fig. 4), a result of its high C concentration (Table 1). Conversely, F4 had a relatively low $\mathrm{C}$ concentration, but represented a large percentage of the soil mass, and thus also accounted for a large proportion of the total soil C. Nitrogen concentration generally dropped with increasing density, except between F1 and F2. F3 and F4 accounted for the bulk of total soil N.

\subsection{Mineralogy of the bulk soil and density fractions}

The bulk soil was dominated by three major phases: plagioclase feldspar, quartz, and smectite (Fig. 5). Traces of pyroxene (enstatite) and a zeolite mineral (possibly heulandite) were also discernible. Peaks representing pedogenic oxides were either not present or concealed by others. There was neither the elevated background usually related to the presence of amorphous glass (as would be seen in a young Andisol) nor the typically very broad 'hump-like' signals representing short-range order components (as would be expected in a soil with high allophane content). Generally, the XRD trace gave the impression of a volcanic soil with little influence of volcanic glass and at a weathering stage in which smectite is accumulating but pedogenic oxides have not yet grown to the sizes of better refracting, larger crystals.

Broad, low intensity signals typical for smaller and less crystalline minerals prevailed in F1 and F2, suggesting that particle sizes and reflecting planes were smaller in these than in the other density fractions. Despite their low signal intensity, the presence of smectite and plagioclase feldspar could be confirmed. The quartz 100 reflection was visible as a sharp peak at $3.34 \AA$. Both patterns clearly indicated a much lower crystallinity of the mineral matrix in F1 and F2 than in the heavier fractions. Smectite particles in F1 and F2 were assumed to be smaller than those in the heavier fractions (indicated by the "line broadening" leading to very broad peaks or mere humps).

F3 and F4 were dominated by the phyllosilicate clay mineral smectite (at $6^{\circ} 2 \theta$ in the bulk soil and at $8^{\circ} 2 \theta$ in the density fractions), producing a peak that greatly overshadowed those of the quartz and plagioclase signals at 3.34 and $3.21 \AA$ (Fig. 5). As the medium used for the density separation was a sodium salt (Na polytungstate), the smectite in the density fractions had been transformed to the $\mathrm{Na}$ form, which was expressed in a contraction from 15.4 to $12.4 \AA$ (comparing bulk soil with the density fractions). F4 also showed the strongest zeolite signal of all density fractions, and exclusively contained two mineral phases refracting at 9.7-9.9 $\AA$ and 10.7 $\AA$. It is known that the interlayer space of Na-smectite varies with relative humidity (Moore and Hower, 1986) leading to discrete thicknesses of 9.6, 12.4, 15.2 and $18 \AA$. We thus attribute the 9.7 signal observed here to a "drier" (and, therefore, slightly heavier) portion of the Na-smectite, which seems to have been specifically isolated by the $2.0 \mathrm{~g} \mathrm{~cm}^{-3}$ density cutoff. The signal at $10.7 \AA$ was tentatively interpreted as representing the early stages of a smectite-illite transition. F5 and F6 were rich in primary minerals but lacked phyllosilicates. F6 was rich in plagioclase feldspar and magnetite, whereas F5 contained abundant quartz but little magnetite. 
$\mathrm{NaF} \mathrm{pH}$ was moderately high in all the heavier fractions (Table 1) indicating the presence of considerable amorphous $\mathrm{Al}$ or $\mathrm{Fe}$. It rose steadily with density up to F3, then remained essentially constant. Magnetic separation showed that F6 was the most Fe-oxide rich, with perhaps a small secondary peak in F2 (Table 1). XRD (Fig. 6) confirmed visual evidence that magnetically separable material in F6 was almost exclusively magnetite with only small amounts of albite, quartz, and hematite.

\subsection{Organic matter composition}

Lignin, as well as cutin and suberin acids, decreased with increasing organo-mineral particle density (Table 1), both decreasing about $75 \%$ from F1 to F6. Lignin oxidation for vanillyl phenols increased monotonically with increasing density, whereas the oxidation index for syringyl phenols showed much less pattern. For most fractions the ratio of cutin and suberin acids to lignin ranged between 2 and 3 except for F3 (ratio 1). Lignin S/V and C/V ratios varied little with density. The values indicate, based upon published values, that gymnosperm needles contribute more lignin to this soil than woody tissue (Hedges and Mann, 1979). They also indicate little contribution by the abundant understory and herbaceous angiosperms, except perhaps to F5 and F6.

\subsection{Isotope patterns}

Radiocarbon values $\left(\Delta^{14} \mathrm{C}\right)$ increased with density, then decreased across F3 to F6, reflecting a decreasing incorporation of "bomb carbon" from atmospheric nuclear weapons testing in the 1960s as well as high charcoal content in F1 and F2. It is likely that much of this charcoal originated from a stand-replacement fire that occurred approximately 500 years ago (Grier and Logan, 1977). The MRTs of F1 and F2 were not calculated, pending isolation and radiocarbon analysis of the charcoal. The MRTs of F3-F6 increased steadily with density. Both ${ }^{13} \mathrm{C}$ and ${ }^{15} \mathrm{~N}$ values increased with density across F1 to F3 (-26.7 to $-24.5 \%$, and 0.03 to $5.42 \%$ ), then leveled off.

30

31

32

33

34

35

36

37

38

39

40

41

42

43

44

45

46

\subsection{Calculated mineral phase densities and organic- vs. mineral-phase volume}

We calculated the range in density of the mineral phase (Table 1) from the $\% \mathrm{C}$ and end-point densities of each fraction, assuming that: (1) the density of the organic phase was $1.4 \mathrm{~g} \mathrm{~cm}^{-3}$ (see Adams, 1973; Mayer et al., in press) and (2) the organic phase of all fractions contained 50\% C. For the five organo-mineral fractions (F2-F6), the calculated mineral-phase density varied erratically between 2.1 and $2.6 \mathrm{~g} \mathrm{~cm}^{-3}$ (Table 1), typical of many primary and secondary soil minerals (Klein and Hurlbut, 1993). Values for all five fractions were higher, however, than the theoretical value for allophane $\left(1.9 \mathrm{~g} \mathrm{~cm}^{-3}\right)$, consistent with the XRD results showing little allophane. The especially high range for $\mathrm{F} 2$ is consistent with the slightly higher level of magnetically separable material in that fraction.

To explore whether heavier particles imply thinner organic layers, we calculated the average volume of the organic phase (layer) relative to the total organo-mineral particle for each density fraction, assuming again a $50 \% \mathrm{C}$ concentration and a density of $1.4 \mathrm{~g} \mathrm{~cm}^{-3}$ for the organic phase. 
Percent organic volume decreased with increasing density from 81 to $2 \%$ (Table 1), as it must given the decreased $\% \mathrm{C}$ and our assumptions. The decreased ratio of organic phase to total volume is consistent with a corresponding decrease in layer thickness. A better estimate of layer thickness, however, will require data on particle size and both mineral- and organic-phase density.

\section{Discussion}

\subsection{Comparison with previous studies}

Our results for OM composition across the density fractions are generally consistent with previously reported results. The peak in the dry-weight distribution of this soil in F4 (Fig. 4) is striking but consistent with the low A-horizon bulk density $\left(0.82 \mathrm{~g} \mathrm{~cm}^{-3}\right)$ typical of the DIRT study-plot soils (Sulzman et al., in press). C and $\mathrm{N}$ concentrations fit well with reports cited in Figs. 1 and 2. $\mathrm{C} / \mathrm{N}$ of F1 and F2 was higher than those reported elsewhere (Fig. 1), probably due to the large amounts of charcoal in our soil sample. $\mathrm{C} / \mathrm{N}$, however, decreased more across the three densest fractions in previous studies than in ours.

The decrease in lignin phenols with increasing density is consistent with previous reports that lignin is not an especially long-lived component of SOM (Nierop, 2001; Nierop and Verstraten, 2003; Rumpel et al., 2004). The lignin phenols that do persist are in an increasingly oxidized state (Table 1), which permits strong sorption to hydroxylated mineral surfaces by ligand exchange. The relatively constant ratio of cutin and suberin acids to lignin phenols, however, indicates that the two classes of compounds are equally distributed across the density series. The ratio of syringyl to vanillyl $(\mathrm{S} / \mathrm{V})$ and cinnamyl to vanillyl $(\mathrm{C} / \mathrm{V})$ compounds for each of the fractions is within the range previously reported for gymnosperm wood and needles (Hedges and Mann, 1979; Opsahl and Benner, 1995).

Baisden et al. (2002) provided the only other published isotope data for SDFs of which we are aware. Some of their soils yielded decreases in $\Delta^{14} \mathrm{C}$ with increasing density but others showed increases or held constant. Their ${ }^{13} \mathrm{C}$ values generally increased with particle density, but interpretation of their results is complicated by their use of sonication before each increase in density, which may have redistributed organics into the higher-density fractions. Also, for several of their soils, their densest fraction $\left(>2.22 \mathrm{~g} \mathrm{~cm}^{-3}\right)$ accounted for virtually all the soil C. This result, at variance with most of the SDF studies cited in Fig. 1, could be a result of unusual soil mineralogy or texture or perhaps an artifact of the repeated sonication.

\subsection{The layer-thickness and "onion" layering hypotheses.}

Given the large differences in mineralogy of the fractions it was difficult to separate effects of OM content on organo-mineral particle density from those of mineral-phase density. Our calculations (Table 1) suggest that variation in mineral-phase density is unlikely to explain all the variation in organo-mineral particle density, whereas $\% \mathrm{C}$ correlated well with particle density, as it has in previous studies (Fig. 2). Our data are also consistent with a decrease in organic layer 
data. SDF of soils of simpler mineralogy (smectite dominated Alfisol and Fe-oxide dominated Oxisol) is underway and may provide more readily interpretable results.

The increase in oxidation index (Ac/Al) for vanillyl (though not syringyl) phenols is consistent with our "onion" layering model, in which carboxylated and peptidic compounds sorb preferentially as a stable inner layer directly on mineral surfaces. The increase in ${ }^{14} \mathrm{C}$ MRT is also consistent, as is the monotonic decrease in $\mathrm{C} / \mathrm{N}$ with increasing density seen for many soils (Fig. 1). The relatively consistent $\mathrm{C} / \mathrm{N}$ across $\mathrm{F} 4-\mathrm{F} 6$ of our forest soil suggests a common organic constituent. Surface-active microbial proteins are an obvious possibility. The role of such proteins in bacterial attachment has been extensively studied (Marshall, 1971; Bitton and Marchall, 1980). Cellular attachment is preceded by protein sorption to mineral surfaces (Bashan and Levanony, 1988; Dufrene et al., 1996, 1999). Mycelial fungi secrete a broad class of surface-active glycoproteins, the hydrophobins, with discrete hydrophilic and hydrophobic domains, allowing formation of amphipathic layers (Wösten, 2001; Wessels, 1997). The ability of hydrophobins to bind to either hydrophilic or hydrophobic surfaces would permit sorption across a range of mineral surfaces. Research into the role of hydrophobins in SOM dynamics has been restricted to one group attributed to arbuscular mycorrhizal fungi, the glomalins, suggested to be a significant component of SOM and agents of aggregate formation (Wright et al., 1999; Franzluebbers et al., 2000; Rillig et al., 2002). The ability of hydrophobins to bind to either hydrophilic or hydrophobic surfaces would permit sorption across a range of mineral surfaces and thus explain to some extent the consistency in organic matter $\mathrm{C} / \mathrm{N}$ across the different types of minerals observed in the three heaviest density fractions. A clearer indication of the relative roles of cation-exchanged peptidic compounds and ligand-exchanged carboxyl compounds in forming the inner layer in an "onion" model requires quantification of these various compounds.

\subsection{Organic matter composition in relation to mineralogy}

Sequential density fractionation (SDF) separated the soil particles into three major groupings. F1 and F2 were mainly plant debris, F3 and F4 accounted for most of the layer silicate clays in this soil, and F5 and F6 contained mainly primary minerals. Differences in OM composition across the fractions must be interpreted in the context of these mineralogical differences.

Most measures of OM composition (Table 1) showed one of two patterns: A, a monotonic change with increasing density, or B, a monotonic change across F1 through F4, then little change across $\mathrm{F} 5$ and $\mathrm{F} 6$. For example, total $\mathrm{C}, \mathrm{N}$, lignin phenols, vanillyl lignin oxidation index, and cutin + suberin acids all showed pattern $\mathrm{A}$, whereas $\mathrm{C} / \mathrm{N},{ }^{13} \mathrm{C},{ }^{15} \mathrm{~N}$, and syringyl lignin oxidation index showed pattern $\mathrm{B}$. Estimates of ${ }^{14} \mathrm{C}$ MRT showed pattern A over the four organo-mineral fractions (F3-F6).

The turnover time for the bulk of the OM increased with increasing organo-mineral particle density in this soil, indicating more stable sorption of the organics with increasing particle density. Because ligand exchange is the most stable of the various sorption mechanisms (Sposito, 1988), the MRTs suggest that ligand exchange becomes more prominent with increasing density, and presumably with decreasing layer thickness. Conversely, the less dense organo-mineral fractions may include more recently stabilized $\mathrm{C}$ in the outer layers of thicker coatings. Thus, 
although the inner layers of these lower density particles may have MRTs similar to those of heavier particles, the average MRT is lower. The increase in lignin oxidation with density is consistent with this pattern, as increased oxidation implies more carboxyl groups available to ligand exchange with the variable-charge (hydroxylated) mineral surfaces. The decrease in $\mathrm{C} / \mathrm{N}$ with density reported for most soils worldwide, though only across the lightest four fractions for this soil, suggests in addition a role for electrostatically-bound peptidic compounds in stable sorption of the inner layers and thus in slow OM turnover.

The ${ }^{14} \mathrm{C}$ MRTs must, however, be considered in the context of the stable isotope data reported here. There is ample evidence that both ${ }^{13} \mathrm{C}$ and ${ }^{15} \mathrm{~N}$ accumulate preferentially as a result of continued microbial processing, though the mechanisms are still unclear (Gleixner et al., 1993; Hayes 2001; Filley et al., 2001; Abraham and Hesse, 2003; Fernandez et al., 2003). The lack of change in ${ }^{13} \mathrm{C}$ and ${ }^{15} \mathrm{~N}$ across the three heaviest fractions might be explained by especially stable sorption (as evidenced by the older C MRTs) with consequently reduced opportunity for further microbial processing and isotope fractionation. In any case, any explanation of isotope fractionation based on microbial processing must explain how enzymes can make contact with, and then cleave, organics that are sorbed to mineral surfaces, especially in the inner layers, access to which by both organisms and enzymes is presumably hindered by overlying organics.

An alternative, though not mutually exclusive, explanation is that organics in the heavier particles were already rich in ${ }^{13} \mathrm{C}$ and ${ }^{15} \mathrm{~N}$ at the time that they sorbed to the mineral surfaces. Lignin as well as cutin and suberin acids, all of which decreased with increasing particle density in our andic soil, are well known to be depleted in ${ }^{13} \mathrm{C}$ relative to bulk plant material (Deines, 1980). Other compounds, especially amino acids, may be enriched or depleted in both ${ }^{13} \mathrm{C}$ and ${ }^{15} \mathrm{~N}$ depending on the specific compound and the substrate on which the organisms that produce the compounds are grown (Macko et al., 1987; Hayes, 2001; Abraham and Hesse, 2003). More information, especially compound-specific ${ }^{15} \mathrm{~N}$ data, will be needed to explore fully this explanation.

\section{Concluding Remarks}

Removal of particulate organic debris (particle density $<1.85 \mathrm{~g} \mathrm{~cm}^{-3}$ ) allowed focus on the mineral-dominated fractions. Subsequent isolation of several sequential density fractions, rather that a single "heavy fraction", then permitted more ready interpretation of the results of ${ }^{14} \mathrm{C},{ }^{13} \mathrm{C}$, ${ }^{15} \mathrm{~N}$, lignin, and other analyses. The sequential fractionation also isolated discrete mineralogies, allowing exploration of relations between mineral surface chemistry and composition of the associated organic matter.

Our data are consistent with an "onion" model of SOM accumulation on mineral surfaces in which polar carboxyl and nitrogenous compounds sorb by ligand and cation exchange. Such organics then provide a relatively nonpolar surface onto which hydrophobic and less polar hydrophilic organics can sorb more stably than they could onto clean mineral surfaces. An "onion" layering model begs questions about mechanisms of renewal and production of clean mineral surfaces in soils. This could occur by breakage of existing primary or secondary minerals, and by aeolian or lateral inputs of new mineral material. Other mechanisms, such as 
incongruent dissolution of primary minerals and subsequent formation of secondary minerals, as well as passage through soil animal guts, may also be important.

Our results also imply that sorption of peptidic organics to soil mineral particles is a potentially important process of $\mathrm{C}$ and $\mathrm{N}$ stabilization and deserves further study. To the extent that the $\mathrm{N}$ containing organics sorb mainly electrostatically, and the non-N-containing organics sorb mainly via ligand exchange and weaker interactions, nitrogenous and non-nitrogenous compounds are stabilized via different mechanisms. This distinction is not reflected in current SOM models of SOM dynamics (Jenkinson et al., 1991; Parton et al. 1991; McGuire et al., 1997; Currie, 2003; Rastetter et al., 2005). A better understanding of the processes that both stabilize and destabilize SOM would improve our ability to predict future trends in agricultural and forest productivity and $\mathrm{C}$ exchange between soil and atmosphere.

\section{Acknowledgements}

We thank the Department of Crops and Soils, Oregon State University, for laboratory facilities, and the H.J. Andrews Long-Term Ecological Research program for logistical support, and S. Reese and L. Nagel for laboratory assistance. Partial funding provided by US National Science Foundation SGER grants to P. Sollins and M. Kramer and by USDA NRI grants to K. Lajtha. This work was performed in part under the auspices of the U.S. Department of Energy by University of California, Lawrence Livermore National Laboratory under Contract No. W-7405Eng-48.

\section{References}

Abraham, W.R., Hesse, C., 2003. Isotope fractionations in the biosynthesis of cell components by different fungi: a basis for environmental carbon flux studies. FEMS Microbiology Ecology 46, 21-128.

Adams, W.A., 1973. The effect of organic matter on the bulk and true densities of some uncultivated podzolic soils. Journal of Soil Science 24, 10-17.

Arnarson, T.S., Keil, R.G., 2001. Organic-mineral interactions in marine sediments studied using density fractionation and X-ray photoelectron spectroscopy. Organic Geochemistry 32:1401-1415.

Aufdenkampe, A., Hedges, J., Richey, J., Krusche, A., Llerena, C. 2001. Sorptive fractionation of dissolved organic nitrogen and amino acids onto fine sediments with the Amazon Basin. Limnology and Oceanography 46, 1921-1935.

Baisden, W.T., Amundson, R., Cook, A.C., and Brenner, D.L., 2002. Turnover and storage of C and $\mathrm{N}$ in five density fractions from California annual grassland surface soils. Global Biogeochemical Cycles 16, 64-1-16.

Burchill, S., Hayes, M.H.B., Greenland, D.J., 1981. Adsorption. In: Greenland, D., Hayes, M. (Eds.), The Chemistry of Soil Surfaces, Wiley, Chichester, pp. 221-400.

Chevallier, T., Muchaonyerwa, P., Chenu, C., 2003. Microbial utilisation of two proteins adsorbed to a vertisol clay fraction: toxin from Bacillus thuringiensis subsp. tenebrionis and bovine serum albumin. Soil Biology \& Biochemistry 35, 1211-1218.

Craig, O.E., Collins, M.J., 2002. The removal of protein from mineral surfaces: Implications for residue analysis of archaeological materials. Journal of Archaeological Science 29, 1077-1082. 
Currie, W. S., 2003. Relationships between carbon turnover and bioavailable energy fluxes in two temperate forest soils. Global Change Biology 9, 919-929.

Dalal, R.C., Mayer, R.J., 1986. Long-term trends in fertility of soils under continuous cultivation and cereal cropping in southern Queensland. IV. Loss of organic carbon for different density functions. Australian Journal of Soil Research 24, 301-309.

De Cristofaro, A., Violante, A., 2001. Effect of hydroxy-aluminium species on the sorption and interlayering of albumin onto montmorillonite. Applied Clay Science 19, 59-67.

Deines, P., 1980. The isotopic composition of reduced organic carbon, In: Fritz, P., and Fontes, J.C. (Eds.), Handbook of Environmental Isotope Geochemistry, Volume 1, The Terrestrial Environment, Elsevier, Amsterdam, pp. 329-406.

DiCosty, R.J., Weliky, D.P., Anderson, S.J., Paul E.A., 2003. N-15-CPMAS nuclear magnetic resonance spectroscopy and biological stability of soil organic nitrogen in whole soil and particle-size fractions. Organic Geochemistry 34, 1635-1650.

Ding, X., Henrichs, S., 2002. Adsorption and desorption of proteins and polyamino acids by clay minerals and marine sediments. Marine Geochemistry 77, 225-237.

Fernandez, I., Mahieu, N., and Cadisch, G., 2003. Carbon isotopic fractionation during decomposition of plant materials of different quality. Global Biogeochemical Cycles 17, 1075.

Filley, T.R., Hatcher, P.G., Shortle, W., 2000 The application of 13C-labeled tetramethylammonium hydroxide thermochemolysis to the study of the fungal degradation of wood. Organic Geochemistry 31, 181-198.

Filley, T.R., Blanchette, R.A., Simpson, E., Fogel, M.L., 2001. Nitrogen cycling by wood decomposing soft-rot fungi in the "King Midas tomb," Gordion, Turkey. Proceedings of the National Academy of Sciences USA 98, 13346-13350.

Gaudinski, J. B., Trumbore, S.E., Davidson, E.A., and Zheng S., 2000. Soil carbon cycling in a temperate forest: radiocarbon-based estimates of residence times, sequestration rates and partitioning of fluxes. Biogeochemistry 51, 33-69.

Gleixner, G., Danier H.J., Werner R.A., Schmidt H.L., 1993. Correlations between the ${ }^{13} \mathrm{C}$ content of primary and secondary plant products in different cell compartments and in decomposing Basidiomycetes. Plant Physiology 102, 1287-1290.

Golchin, A., Baldock J., Clarke P., Higashi T., Oades J.M., 1997. The effects of vegetation and burning on the chemical composition of soil organic matter of a volcanic ash soil as shown by ${ }^{13}$ C-NMR spectroscopy. 2. Density fractions. Geoderma 76, 175-192.

Golchin, A., Oades J.M., Skjemstad J.O., Clarke P., 1994. Soil structure and carbon cycling. Australian Journal of Soil Research 32, 1043-1068.

Goñi M. A., Hedges J. I., 1990. Potential applications of cutin-derived CuO reaction products for discriminating vascular plant sources in natural environments. Geochimica et Cosmochimica Acta 54, 3073-3081.

Hayes, J.M., 2001. Fractionation of carbon and hydrogen isotopes in biosynthetic processes. In: Valley, J.W., Cole D.R. (Eds.), Stable Isotope Geochemistry: Reviews in Mineralogy and Geochemistry. Mineralogical Society of America, Blacksburg, VA, pp. 662-.

Hua, Q., Barbetti, M., 2004. Review of tropospheric bomb ${ }^{14} \mathrm{C}$ data for carbon cycle modeling and age calibration purposes. Radiocarbon 46, 1273-1298.

Hedges J.I., Mann, D.C., 1979. The characterization of plant tissues by their lignin oxidation products. Geochimica et Cosmochimica Acta 43, 1803-1807. 
Hedges, J., Hare, P., 1987. Amino acid adsorption by clay minerals in distilled water. Geochimica et Cosmochimica Acta 51, 255-259.

Hedges J.I., Clark, W.A., Cowie, G.L., 1988. Organic matter sources to the water column and surficial sediments of a marine bay. Limnology and Oceanography 33, 1116-1136.

Grier, C., Logan, R., 1977. Old-growth Pseudotsuga menziesii communities of a western Oregon watershed; biomass distribution and production budgets. Ecological Monographs 47, 373-400.

Jenkinson, D.S., Adams, D.E., Wild, A., 1991. Model estimates of $\mathrm{CO}_{2}$ emissions from soil in response to global warming. Nature 351, 304-306.

Kaiser, K., Guggenberger, G., 2003. Mineral surfaces and soil organic matter. European Journal of Soil Science 54, 219-236.

Klein C., Hurlbut, C.S., 1993. Handbook of Mineralogy, Wiley, New York, 681 pp.

Knicker, H., 2000. Biogenic nitrogen in soils as revealed by solid-state carbon-13 and nitrogen15 nuclear magnetic resonance spectroscopy. Journal of Environmental Quality 29, 715723.

Knicker, H., Schmidt, M.W.I., Kögel-Knabner, I., 2000. Nature of organic nitrogen in fine particle size separates of sandy soils of highly industrialized areas as revealed by NMR spectroscopy. Soil Biology \& Biochemistry 32, 241-252.

Lajtha, K., Crow, S., Yano,Y., Kaushal, S.S., Sulzman, E.W., Spears, J.D.H., 2005. Detrital controls on soil solution $\mathrm{N}$ and dissolved organic matter in soils: a field experiment. Biogeochemistry (in press).

Levin, I., Kromer, B., 2004. The tropospheric ${ }^{14} \mathrm{CO}_{2}$ level in mid-latitudes of the northern hemisphere (1959-2003). Radiocarbon 46, 1261-1272.

Macko, S.A., Fogel, M.L., Hare, P.E., Hoering, T.C., 1987. Isotopic fractionation of nitrogen and carbon in the synthesis of amino acids by microorganisms. Chemical Geology 65, 79-82.

Martens, D., Loeffelmann, K., 2003. Soil amino acid composition by acid hydrolysis and anion chromatography-pulsed amperometry. Journal of Agricultural and Food Chemistry 51, 6521-6529.

Mayer, L.M., 1999. Extent of coverage of mineral surfaces by organic matter in marine sediments. Geochimica et Cosmochimica Acta 63, 207-215.

Mayer, L.M., Shick, L., Sawyer, T., Plante, C., Jumars, P., and Self, R., 1995. Bioavailable amino acids in sediments: A biomimetic, kinetics-based approach. Limnology and Oceanography 40, 511-520

Mayer, L.M., Schick, L.L., Hardy, K.R., Wagai R., McCarthy, J., Organic matter in small mesopores in sediments and soils. Geochimica et Cosmochimica Acta (in press)

MacEwan, D.M C., 1961. The montmorillonite minerals. In:(Brindley, G.W., Brown, G.) The Xray Identification and Crystal Structures of Clay Minerals, Mineralogical Society of Great Britain Monograph 5, London, pp. 143-207

McGuire, A.D., Melillo, J M., Kicklighter, D.W., Pan,Y., Xiao, X., Helfrich, J., Moore, B., III, Vorosmarty, C. J., Schloss, A. L., 1997. Equilibrium responses of global net primary production and carbon storage to doubled atmospheric carbon dioxide: Sensitivity to changes in vegetation nitrogen concentration. Global Biogeochemical Cycles 11, 173189.

Mertz, C., Kleber, M., Jahn, R., 2005. Soil organic matter stabilization pathways in clay subfractions from a time series of fertilizer deprivation. Organic Geochemistry (in press). 
Moore, D. M., Hower, J., 1986. Ordered interstratification of dehydrated and hydrated Nasmectite. Clays and Clay Minerals 34, 379-84

Murphy, E.M., Zachara, J., Smith S., 1990. Influence of mineral-bound humic substances on the sorption of hydrophobic organic compounds. Environmental Science and Technology 24, $1507-1516$

Nierop, K., 2001. Temporal and vertical organic matter differentiation along a vegetation succession as revealed by pyrolysis and thermally assisted hydrolysis and methylation. Journal of Analytical Applied Pyrolysis 61, 111-132.

Nierop, K., Verstraten, J., 2003. Organic matter formation in sandy subsurface horizons of Dutch coastal dunes in relation to soil acidification. Organic Geochemistry 34, 499-513

Oades, J.M., 1989. An introduction to organic matter in mineral soils. In: (Dixon, J.B., Weed, S.B. Eds.) Minerals in Soil Environments, 2nd ed., Soil Science Society of America, Madison, WI, pp. 89-159.

Opsahl, S., Benner, R., 1995. Early diagenesis of vascular plant tissues; lignin and cutin decomposition and biogeochemical implications. Geochimica et Cosmochimica Acta 59, 4889-4904.

Parton, W.J., Agren, G.I., McMurtrie, R.E., Pastor, J., Shugart, H.H., 1991. State-of-the-art of models of production - decomposition linkages in conifer and grassland ecosystems. Ecological Applications 1, 118-138.

Rastetter, E.B., Perakis, S.S., Shaver, G.R., Ågren, G. I., 2005. Terrestrial C sequestration at elevated $\mathrm{CO}_{2}$ and temperature: the role of dissolved organic $\mathrm{N}$ loss. Ecological Applications 15, 71-86.

Rillig, M.C., Wright, S.F., Torn, M.S., 2001. Unusually large contribution of arbuscular mycorrhizal fungi to soil organic matter in tropical forest soils. Plant and Soil 233, 167177.

Rumpel, C., Eusterheus, K., Kögel-Knabner, I., 2004. Location and chemical composition of stabilized organic carbon in topsoil and subsoil horizons of two acid forest soils. Soil Biology \& Biochemistry 36, 177-190.

Schulten, H.R., Schnitzer, M., 1998. The chemistry of soil organic nitrogen: a review. Biology and Fertility of Soils 26, 1-15.

Schmidt-Rohr, K., Mao, J.-D., Olk, D.C., 2004. Nitrogen-bonded aromatics in soil organic matter and their implications for a yield decline in intensive rice cropping. Proceedings of the National Academy of Science USA 101, 6351-6354.

Smernik, R.J., Baldock, J.A., 2005. Does solid-state 15N NMR spectroscopy detect all soil organic nitrogen? Biogeochemistry (in press).

Sollins, P., Spycher, G., and Topik, C., 1983. Processes of soil organic-matter accretion at a mudflow chronosequence, Mt Shasta, California. Ecology 64, 1273-1282.

Soil Survey Staff. 1999. Soil Taxonomy: A Basic System of Soil Classification for Making and Interpreting Soil Surveys. 2nd ed. USDA Natural Resources Conservation Service, Agricultural Handbook 436, U.S. Government Printing Office, Washington, DC. 869 pp.

Sposito, G. 1984. The Surface Chemistry of Soils, Oxford, New York, NY. 234 p.

Sposito, G. 1989. The Chemistry of Soils, Oxford, New York, NY. 277 p.

Spycher, G., Rose, S., Sollins, P., Norgren, J., Young, J.L., and Cromack, K. Jr., 1986. Evolution of structure in a chronosequence of andesitic forest soils. Soil Science 142, 173-178. 
Strickland, T. C., Sollins, P., Rudd, N., Schimel, D.S., 1992. Rapid stabilization and mobilization of ${ }^{15} \mathrm{~N}$ in forest and range soils. Soil Biology \& Biochemistry 24, 949-855.

Stuiver, M., Polach, H.A., 1977. Reporting of C-14 data. Radiocarbon 19, 355-363.

Stuiver, M., Reimer, P.J., Braziunas, T.F., 1998. High-precision radiocarbon age calibration for terrestrial and marine samples. Radiocarbon 40,1127-1151.

Sulzman, E.W., Brant, J.B., Bowden, R.D., Lajtha K., 2005. Contribution of aboveground litter, belowground litter, and rhizosphere respiration to total soil $\mathrm{CO}_{2}$ efflux in an old growth coniferous forest. Biogeochemistry 73, 231-256.

Swanson, F.J., James, M.E., 1975. Geology and Geomorphology of the H.J. Andrews Experimental Forest, Western Cascades, Oregon. US Forest Service Research Paper PNW-188, Portland, OR.

Swanston, C.W., Torn, M.S., Hanson, P.J., Southon, J.R., Garten, C.T., Hanlon, E.M., Ganio, L., 2005. Initial characterization of processes of soil carbon stabilization using forest standlevel radiocarbon enrichment. Geoderma 128, 52-62.

Theng, B. 1979. Formation and Properties of Clay-Polymer Complexes. Elsevier, Amsterdam.

Torn, M.S., Lapenis, A.G., Timofeev, A., Fischer, M.L., Babikov, B.V., Harden, J.W., 2002. Organic carbon and carbon isotopes in modern and 100-year-old-soil archives of the Russian steppe. Global Change Biology 8, 941-953.

Trumbore, S.E., 1993. Comparison of carbon dynamics in tropical and temperate soils using radiocarbon measurements. Global Biogeochemical Cycles 7, 275-290.

Trumbore, S.E., Davidson, E.A., Decamargo, P.B., Nepstad, D.C., Martinelli, L.A.. 1995. Belowground cycling of carbon in forests and pastures of eastern Amazonia. Global Biogeochemical Cycles 9, 515-528.

Turchenek, L.W., Oades, J.M., 1979. Fractionation of organomineral complexes by sedimentation and density techniques. Geoderma 21,311-343.

Vogel, J.S., Southon, J.R., Nelson, D.E., Brown, T.A., 1984. Performance of catalytically condensed carbon for use in accelerator mass-spectrometry nuclear instrumentation methods, Physical Reviews, Sect. B-Beam Interaction Material Atoms 233, 289-293.

Wang, X.-C., Lee, C., 1993. Adsorption and desorption of aliphatic amines, amino acids and acetate by clay minerals and marine sediments. Marine Chemistry 44, 1-23.

Wershaw, R.L., 2004. Evaluation of Conceptual Models of Natural Organic Matter (Humus) from a Consideration of the Chemical and Biochemical Processes of Humification. Scientific Investigations Report 2004-5121, U.S. Geological Survey Information Services, Denver, CO

Wessels, J.G., 1997. Hydrophobins: proteins that change the nature of the fungal surface. Advances in Microbial Physiology 38, 1-45.

Wösten, H.A.B., 2001. Hydrophobins: multipurpose proteins. Annual Review of Microbiology $55,625-646$.

Wright, S.F., Upadhyaya, A., 1996. Extraction of an abundant and unusual protein from soil and comparison with hyphal protein of arbuscular mycorrhizal fungi. Soil Science 161, 575-586.

Young, J.L., Spycher, G., 1979. Water dispersible soil organic-mineral particles. Soil Science Society America Journal 43, 324-328.

Zimmerman, A., Goyne, K., Chorover, J., Komarneni, S., Brantley, S., 2004. Mineral mesopore effects on nitrogenous organic matter adsorption. Organic Geochemistry 35, 355-375. 
Table 1

Measured and calculated properties of the 6 density fractions.

\begin{tabular}{|c|c|c|c|c|c|c|}
\hline & \multicolumn{6}{|c|}{ Fraction density $\left(\mathrm{g} \mathrm{cm}^{-3}\right)$} \\
\hline & F1 & F2 & F3 & F4 & F5 & F6 \\
\hline & $<1.65$ & $1.65-1.85$ & $1.85-2.00$ & $2.00-2.28$ & $2.28-2.55$ & $>2.55$ \\
\hline Dry mass (\% of soil) & 2.98 & 1.84 & 10.7 & 57.5 & 16.9 & 10.1 \\
\hline $\mathrm{pH}$ in $\mathrm{NaF}$ & 8.7 & 9.1 & 9.6 & 9.9 & 10.0 & 9.8 \\
\hline Magnetic mass (\% of fraction) & 0.07 & 0.29 & 0.20 & 0.13 & 0.08 & 10.5 \\
\hline Total C (\% of fraction) & 36.0 & 28.5 & 14.1 & 2.69 & 0.74 & 0.22 \\
\hline Total N (\% of fraction) & 0.54 & 0.55 & 0.46 & 0.23 & 0.062 & 0.019 \\
\hline $\mathrm{C}: \mathrm{N}$ ratio & 66 & 52 & 30 & 12 & 12 & 12 \\
\hline$\Delta{ }^{14} \mathrm{C}$ concentration $(\%)$ & 6 & 36 & 55 & 30 & -59 & -95 \\
\hline${ }^{14} \mathrm{C}$ mean residence time (y) & ND & ND & 150 & 210 & 680 & 985 \\
\hline$\delta^{13} \mathrm{C}(\%)$ & -26.67 & -26.21 & -25.93 & -24.50 & -24.73 & -24.66 \\
\hline$\delta^{15} \mathrm{~N}(\%)$ & 0.03 & 2.67 & 4.19 & 4.80 & 5.42 & 4.83 \\
\hline Total lignin yield $\left(\mathrm{mg} \mathrm{g}^{-1} \mathrm{C}\right)$ & 31 & 25 & 19 & 16 & 8.4 & 7.8 \\
\hline $\begin{array}{l}\text { Lignin oxidation index } \\
\text { (vanillyl) }^{\mathrm{a}}\end{array}$ & 0.49 & 0.71 & 0.92 & 1.31 & 1.38 & 1.48 \\
\hline $\begin{array}{l}\text { Lignin oxidation index } \\
\text { (syringyl) }^{\mathrm{a}}\end{array}$ & 0.51 & 0.48 & 0.72 & 0.97 & 0.70 & 0.76 \\
\hline Cutin + suberin acids $\left(\mathrm{mg} \mathrm{g}^{-1} \mathrm{C}\right)$ & 66 & 77 & 58 & 19 & 14 & 16 \\
\hline $\mathrm{C} / \mathrm{V}(\mathrm{S} / \mathrm{V})^{\mathrm{b}}$ & $0.17(0.02)$ & $0.29(0.02)$ & $0.25(0.04)$ & $0.28(0.07)$ & $0.22(0.23)$ & $0.25(0.31)$ \\
\hline $\begin{array}{l}\text { Calculated mineral-phase } \\
\text { density range }\left(\mathrm{g} \mathrm{cm}^{-3}\right)\end{array}$ & n.a. & $2.2-3.2$ & $2.1-2.4$ & $2.1-2.3$ & $2.3-2.6$ & $>2.6$ \\
\hline $\begin{array}{l}\text { Volume of organic phase } \\
\text { relative to total particle } \\
\text { volume }(\%)\end{array}$ & 100 & 58 & 29 & 5.5 & 1.5 & 0.4 \\
\hline
\end{tabular}

${ }^{a}$ Ratio of carboxylic acid to aldehyde functional groups for vanillyl lignin phenols.

${ }^{b}$ Ratio of the sum of cinnamyl (or syringyl) phenols to vanillyl phenols.

n.a. -- not applicable 
Fig. 1. C:N ratio vs. particle density for soils worldwide and the andic soil studied here.

Fig. 2. Particle density vs. $\% \mathrm{C}$ for soils worldwide and the andic soil studied here.

Fig. 3. Light microscope images of the 6 density fractions. Note large charcoal fragments in the lightest two fractions.

Fig. 4. Dry weight, $\mathrm{C}$ and $\mathrm{N}$ across density fractions as $\%$ of total amount of each in whole soil.

Fig. 5. X-ray diffraction traces (cobalt radiation) for bulk soil and the 6 density fractions $\left(\mathrm{g} \mathrm{cm}^{-3}\right)$. $\mathrm{P}$ $=$ plagioclase feldspar, $\mathrm{Q}=$ quartz, $\mathrm{Mg}=$ magnetite, $\mathrm{Py}=$ pyroxene, $\mathrm{Sm} 15.4=15.4 \AA$ signal of unaltered smectite (probably Ca-saturated), Sm $12.4=12.4 \AA$ signal of Na-saturated smectite after treatment with $\mathrm{Na}$ - polytungstate. Numbers 1,2,3 indicate $12.24 \AA$ : $10.68 \AA ; 9.90 \AA$ signals in 2.28 $-2.55 \mathrm{~g} \mathrm{~cm}^{-3}$ density fractions, respectively. The [02,11]; [13,20] and [060] signals are hk reflections of smectite (MacEwan, 1961). Compared with bulk soil, the density fractions show a slight displacement of the phyllosilicate prism reflections $[02,11 ; 13,20]$ as a result of Na-saturation.

Fig. 6. X-ray diffraction traces for magnetic and non-magnetic portions of bulk soil and for the heaviest density fraction $\left(>2.55 \mathrm{~g} \mathrm{~cm}^{-3}\right) . \mathrm{P}=$ plagioclase feldspar, $\mathrm{Q}=$ quartz, $\mathrm{Py}=$ pyroxene, $\mathrm{Hm}=$ hematite. Q 100: Q 101 and Hm 104 are hkl reflections of quartz and hematite, respectively. Unlabeled numbers are hkl reflections of magnetite. 


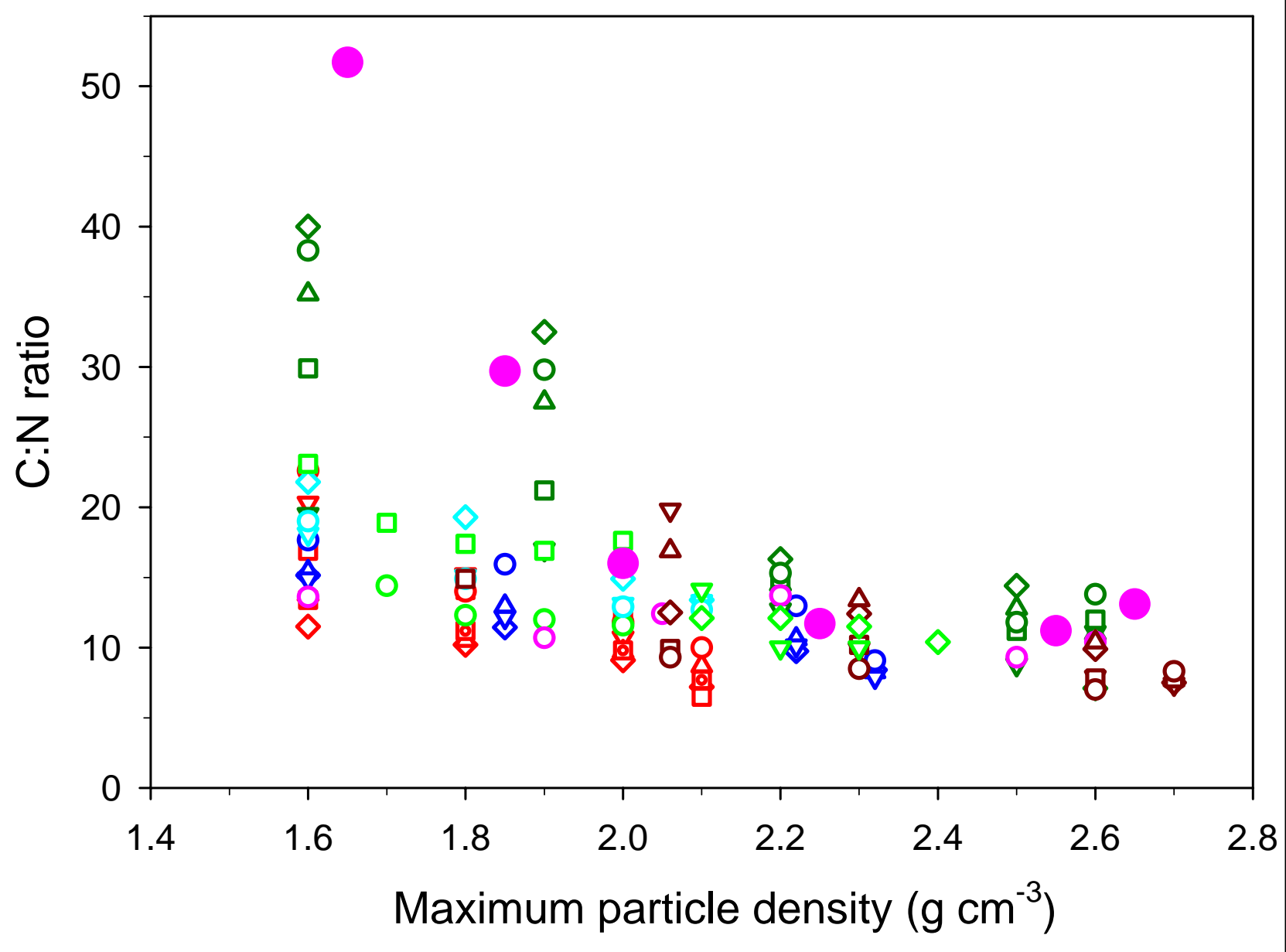

Andic Dystrudept (this study)

O Marine sediment (Arnarson and Keil, 2001)

$\diamond$ Haploxerolls, 3ky unit (Baisden et al., 2002)

$\Delta$ Haploxeralfs, 200ky unit (Baisden et al., 2002)

$\boldsymbol{\nabla}$ Alfisols, 600ky unit (Baisden et al., 2002)

O Alfisols, 3my unit (Baisden et al., 2002)

$\checkmark$ Chromustert, Qld (Golchin et al., 1994a,b)

$\nabla$ Pellustert (Golchin et al., 1994a,b)

$\Delta$ Rhodoxeralf (Golchin et al., 1994a,b)

回 Hapludalf (Golchin et al., 1994a,b)

ㅁ Chromustert, Vic (Golchin et al., 1994b)

O Natrixeralf (Golchin et al., 1994a,b)

$\checkmark$ Andisol, grassland (Golchin et al., 1997)

$\nabla \quad$ Andisol, afforested (Golchin et al., 1997)

- Andisol, forest (Golchin et al., 1997)

$\checkmark$ Xeropsamment, Mudflow A (Sollins et al., 1983)

$\nabla$ Xeropsamment, Mudflow B (Sollins et al., 1983)

$\Delta$ Xeropsamment, Mudflow C (Sollins et al., 1983)

․ Xeropsamment, Mudflow D (Sollins et al., 1983)

O Andisol (Sollins et al., 1983)

$\diamond \quad$ Haploboroll, $>200 \mu \mathrm{m}$ (Turchenek and Oades, 1979)

$\boldsymbol{\nabla}$ Haploboroll, 20-5 $\mu \mathrm{m}$ (Turchenek and Oades, 1979)

$\Delta$ Haploboroll, 5-2 $\mu \mathrm{m}$ (Turchenek and Oades, 1979)

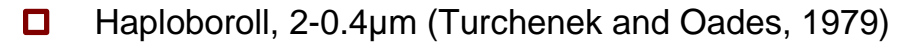

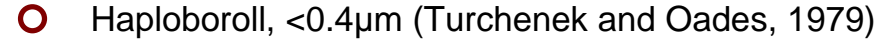

$\checkmark$ Haplohumult, clay-size (Young and Spycher, 1979)

$\square$ Sideraquod, clay-size (Young and Spycher, 1979)

O Dystrandept (Young and Spycher, 1979)

$\nabla \quad$ Argixeroll, clay-size (Young and Spycher, 1979) 


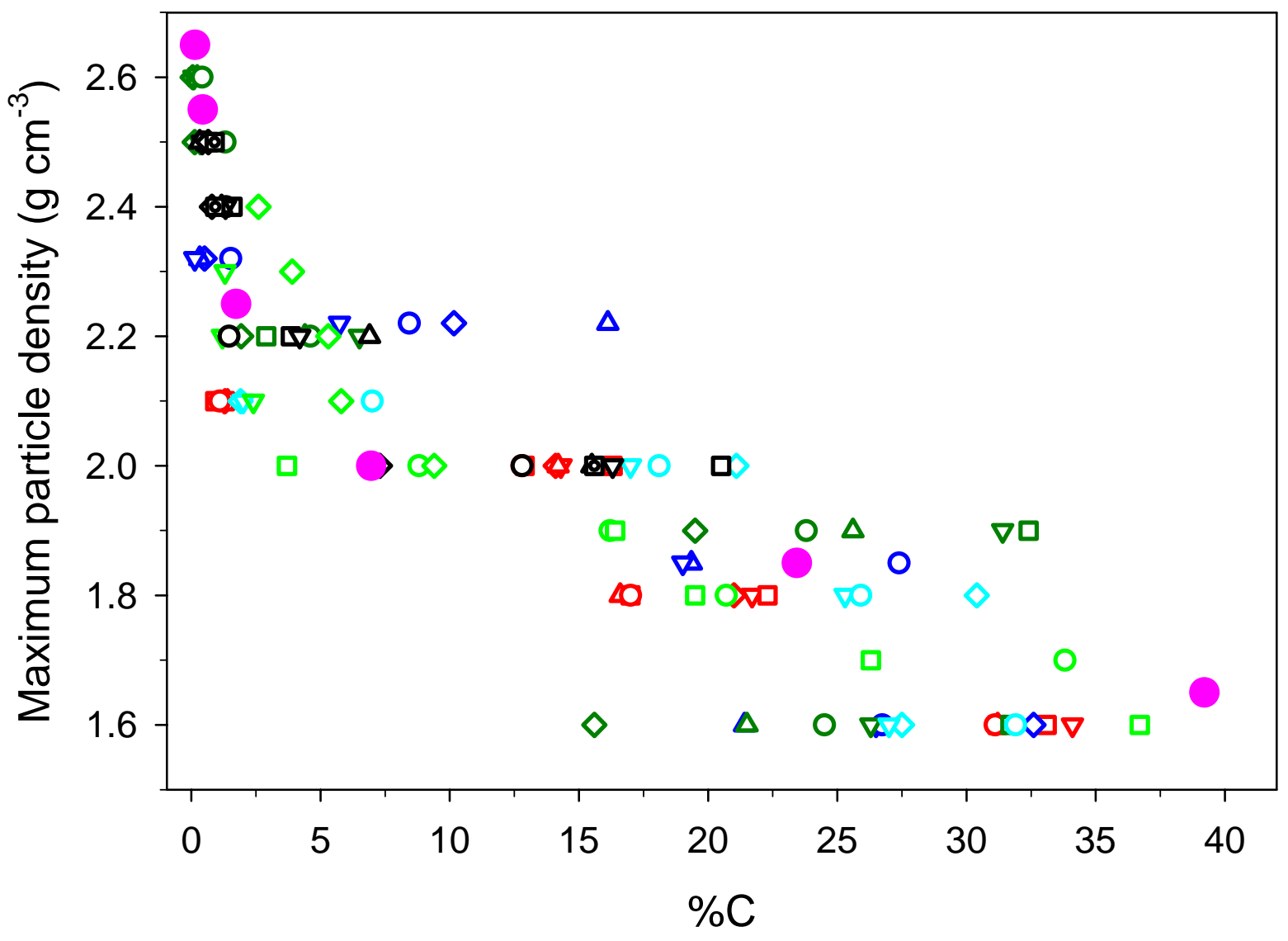

Andic Dystrudept (this study)

$\diamond \quad$ Haploxerolls, 3ky unit (Baisden et al., 2002)

$\Delta$ Haploxeralfs, 200ky unit (Baisden et al., 2002)

$\boldsymbol{\nabla}$ Alfisols, 600ky unit (Baisden et al., 2002)

O Alfisols, 3my unit (Baisden et al., 2002)

O Waco series (Dalal and Mayer, 1986)

- Langlands-Logie series (Dalal and Mayer, 1986)

$\boldsymbol{\nabla}$ Cecilvale series (Dalal and Mayer, 1986)

$\Delta \quad$ Billa Billa series (Dalal and Mayer, 1986)

$\diamond \quad$ Thallon series (Dalal and Mayer, 1986)

回 Riverview series (Dalal and Mayer, 1986)

$\diamond \quad$ Chromustert, Qld (Golchin et al., 1994a,b)

$\boldsymbol{\nabla}$ Pellustert (Golchin et al., 1994a,b)

$\Delta \quad$ Rhodoxeralf (Golchin et al., 1994a,b)

回 Hapludalf (Golchin et al., 1994a,b)

ㅁ Chromustert, Vic (Golchin et al., 1994b)

O Natrixeralf (Golchin et al., 1994a,b)

$\checkmark$ Andisol, grassland (Golchin et al., 1997)

$\checkmark$ Andisol, afforested (Golchin et al., 1997)

- Andisol, forest (Golchin et al., 1997)

$\diamond$ Xeropsamment, Mudflow A (Sollins et al., 1983)

$\nabla$ Xeropsamment, Mudflow B (Sollins et al., 1983)

$\Delta$ Xeropsamment, Mudflow C (Sollins et al., 1983)

口 Xeropsamment, Mudflow D (Sollins et al., 1983)

O Andisol (Sollins et al., 1983)

$\checkmark \quad$ Haplohumult, clay-size (Young and Spycher, 1979)

$\square \quad$ Sideraquod, clay-size (Young and Spycher, 1979)

- Dystrandept (Young and Spycher, 1979)

$\nabla \quad$ Argixeroll, clay-size (Young and Spycher, 1979) 


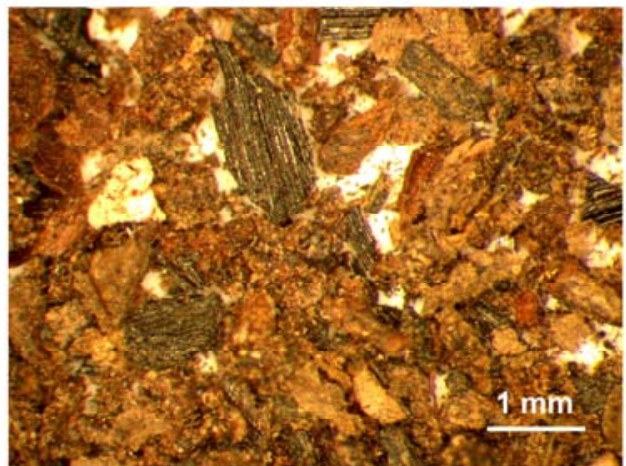

$<1.65 \mathrm{~g} \mathrm{~cm}^{-3}$

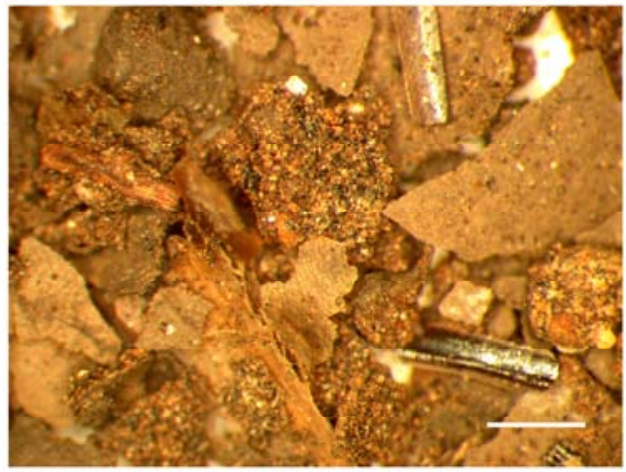

$1.65-1.85$

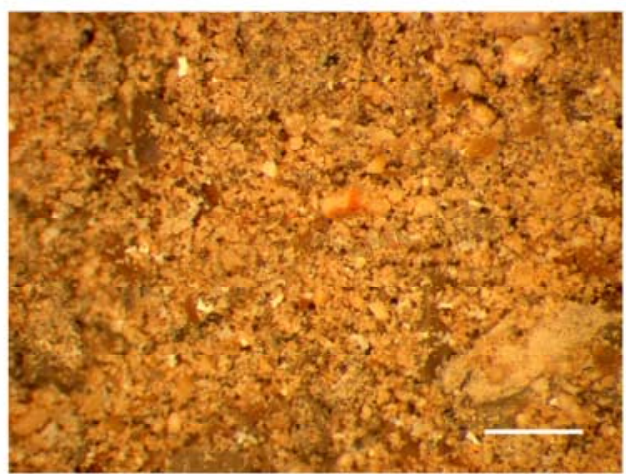

$1.85-2.00$

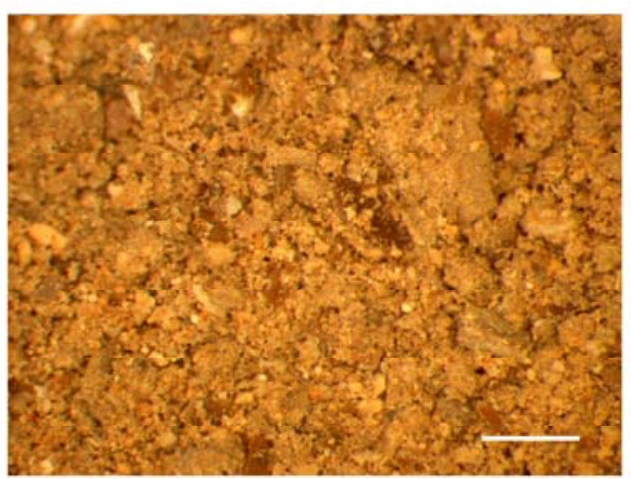

$2.00-2.28$

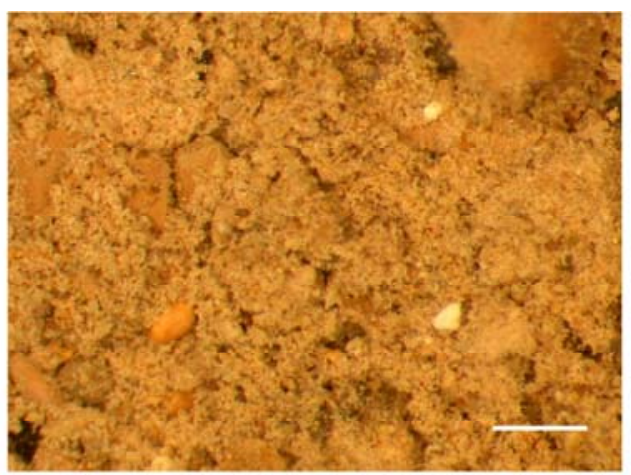

$2.28-2.60$

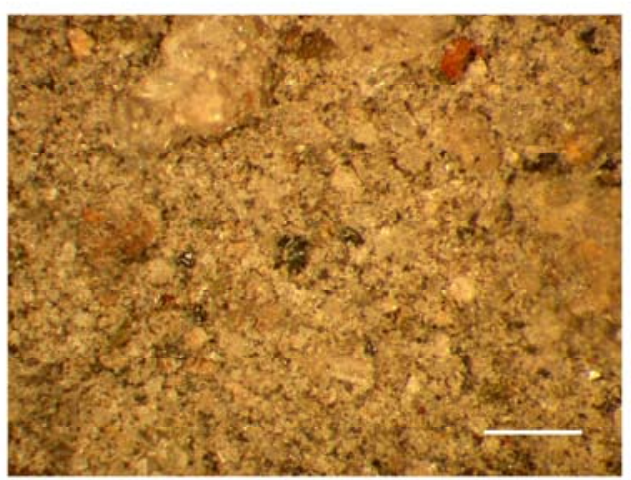

$>2.60$

Fig. 3. Light microscope images of the six density fractions. 


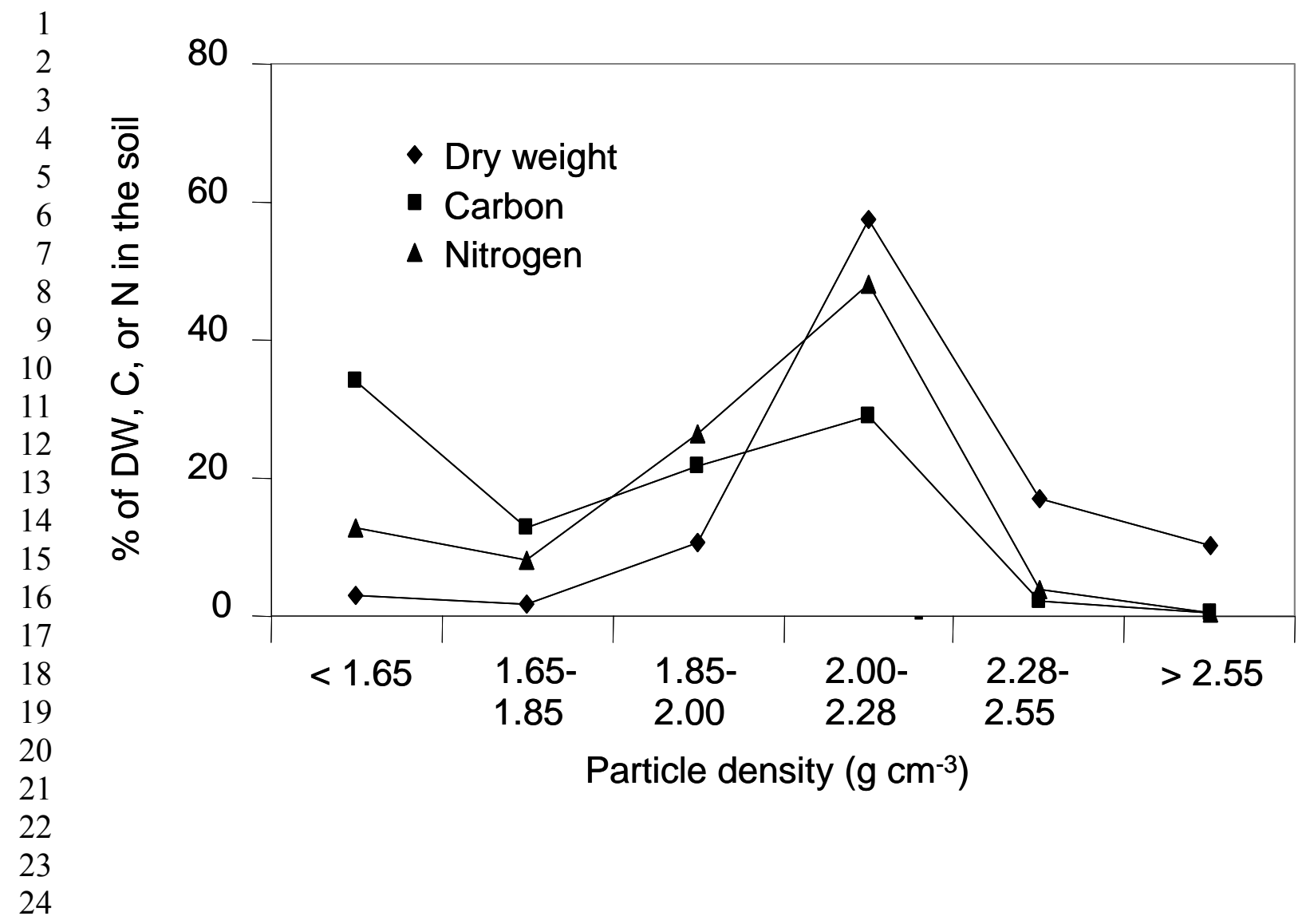

25 Fig. 4. Dry weight, $\mathrm{C}$ and $\mathrm{N}$ across density fractions as $\%$ of total amount of each in whole soil. 


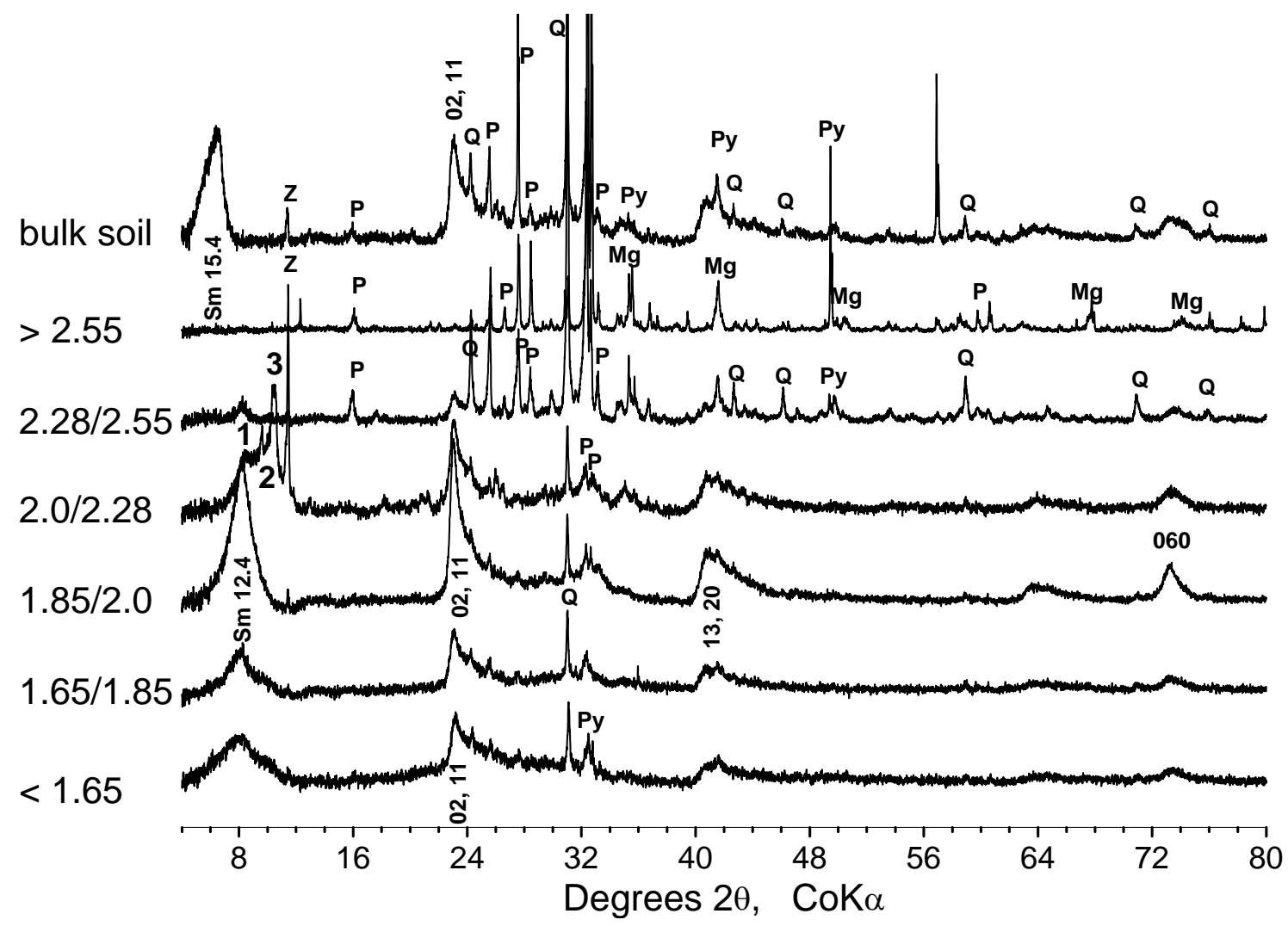

Fig. 5. X-ray diffraction traces (cobalt radiation) for bulk soil and the 6 density fractions $\left(\mathrm{g} \mathrm{cm}^{-3}\right)$. $\mathrm{P}$ $=$ plagioclase feldspar, $\mathrm{Q}=$ quartz, $\mathrm{Mg}=$ magnetite, $\mathrm{Py}=$ pyroxene, $\mathrm{Sm} 15.4=15.4 \AA$ signal of unaltered smectite (probably Ca-saturated), Sm $12.4=12.4 \AA$ signal of Na-saturated smectite after treatment with $\mathrm{Na}$ - polytungstate. Numbers 1,2,3 indicate $12.24 \AA$ : $10.68 \AA ; 9.90 \AA$ signals in 2.28 $-2.55 \mathrm{~g} \mathrm{~cm}^{-3}$ density fractions, respectively. The $[02,11] ;[13,20]$ and [060] signals are hk reflections of smectite (MacEwan, 1961). Compared with bulk soil, the density fractions show a slight displacement of the phyllosilicate prism reflections $[02,11 ; 13,20]$ as a result of Na-saturation. 


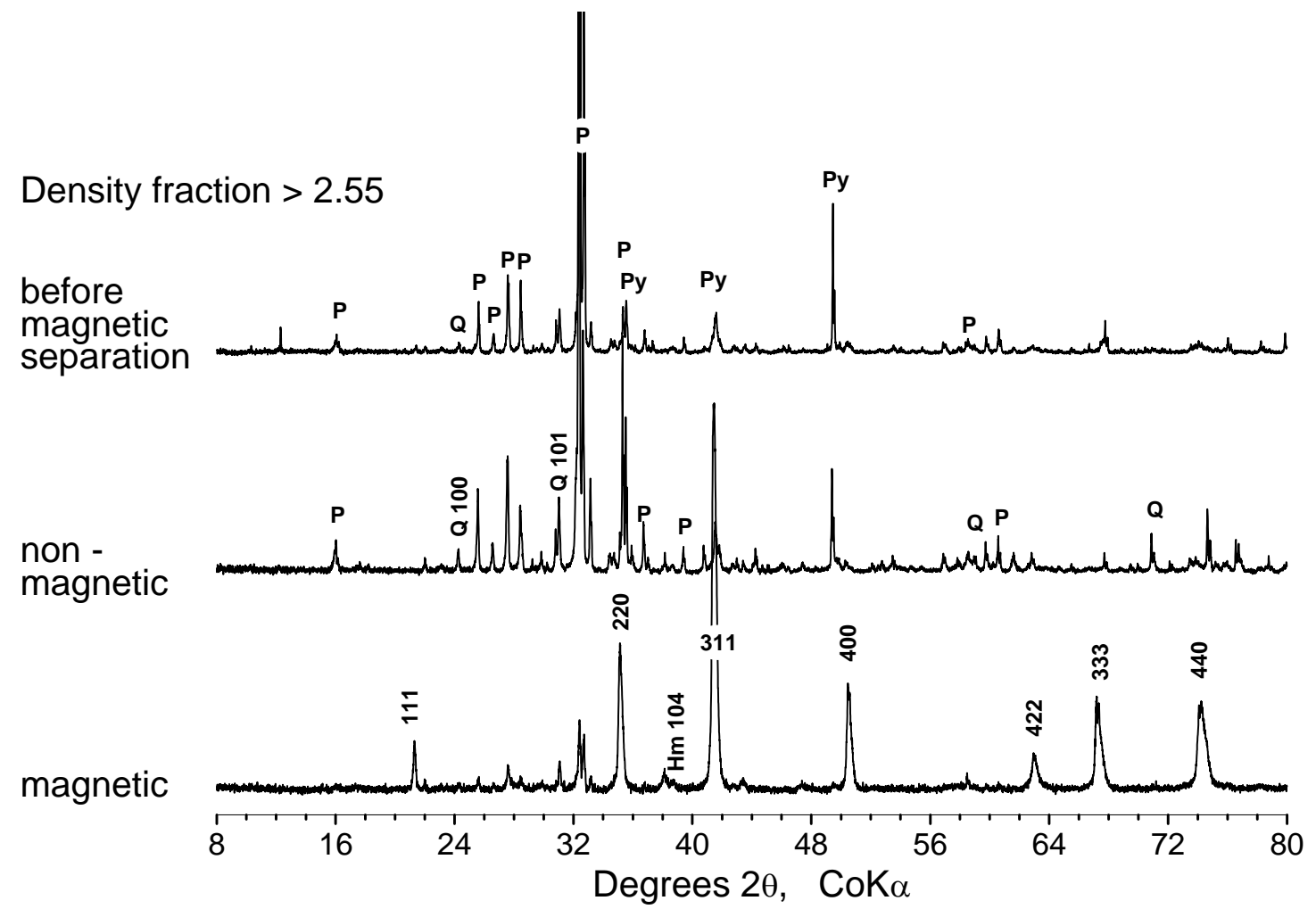

Fig. 6. X-ray diffraction traces for magnetic and non-magnetic portions of bulk soil and for the heaviest density fraction $\left(>2.55 \mathrm{~g} \mathrm{~cm}^{-3}\right) . \mathrm{P}=$ plagioclase feldspar, $\mathrm{Q}=$ quartz, $\mathrm{Py}=$ pyroxene, $\mathrm{Hm}$ $=$ hematite. Q 100: Q 101 and Hm 104 are hkl reflections of quartz and hematite, respectively. Unlabeled numbers are hkl reflections of magnetite. 